\title{
Penatalaksanaan Multirinosinusitis Kronis dengan Komplikasi Abses Subperiosteal Sinistra
}

\author{
Dolly Irfandy ${ }^{1}$, Desy Ambriani ${ }^{2}$, Havriza Vitresia ${ }^{3}$
}

\begin{abstract}
Abstrak
Abses subperiosteal merupakan salah satu komplikasi dari rinosinusitis baik akut ataupun kronis. Beberapa faktor sangat berperan sebagai penyebab penyebaran rinosinusitis ke orbita. Diagnosis rinosinusitis kronik dengan komplikasi abses periorbita ditegakkan berdasarkan anamnesis, pemeriksaan fisik, nasoendoskopi, tomografi komputer serta Magnetic Resonance Imaging (MRI). Penatalaksanaan rinosinusitis kronis dengan komplikasi abses subperiosteal adalah pemberian medikamentosa antibiotik intravena spektrum luas atau kombinasi, dekongestan, kortikosteroid sistemik disertai dengan tindakan operatif yaitu pendekatan Bedah Sinus Endoskopi Fungsional (BSEF). Dilaporkan satu kasus rinosinusitis kronis dengan komplikasi abses subperiosteal kiri pada laki-laki umur 40 tahun dan telah dilakukan perawatan dan dilanjutkan dengan pembedahan melalui pendekatan BSEF. Rinosinusitis kronik dengan komplikasi abses subperiosteal dapat ditatalaksana dengan terapi antibiotik dan pembedahan. Keterlambatan penanganan mempengaruhi tingkat kerusakan. Penanganan dengan antibiotik yang adekuat dan BSEF memberikan prognosis yang baik pada pasien.
\end{abstract}

Kata kunci: abses subperiosteal, BSEF, rinosinusitis kronik

\begin{abstract}
The subperiosteal abscess is a complication of acute or chronic rhinosinusitis. Several factors play an important role as a cause of rhinosinusitis spreading into orbita. Definite diagnosis of chronic rhinosinusitis with subperiosteal abscess complication was established based on history, physical examination, nasoendoscopy, imaging modalities like computed tomography and Magnetic Resonance Imaging (MRI). The management of chronic rhinosinusitis with complication subperiosteal abscess consists of broad-spectrum intravenous antibiotics or combinations, decongestants, systemic corticosteroids then followed by Functional Endoscopic Sinus Surgery (FESS ). It has been reported a case of chronic rhinosinusitis with complications subperiosteal abscess in 40 years male patient. The patient had been given adequate antibiotics then followed with FESS. Chronic rhinosinusitis with complication subperiosteal abscess can be managed with adequate antibiotics therapy and surgery. Delay in treatment could affect the level of damage. Treatment with adequate antibiotics and followed by FESS resulted in a good prognosis and better outcome.
\end{abstract}

Keywords: chronic rhinosinusitis, functional endoscopic sinus surgery, subperiosteal abscess

\footnotetext{
Affiliasi penulis: ${ }^{1}$ Bagian THT-KL, Fakultas Kedokteran, Universitas Andalas, Padang, Indonesia. ${ }^{2}$ Program Pendidikan Dokter Spesialis THT-KL, Fakultas Kedokteran, Universitas Andalas, Padang, Indonesia. ${ }^{3}$ Bagian IImu Kesehatan Mata, Fakultas Kedokteran, Universitas Andalas, Padang, Indonesia.

Korespondensi: dollyirfandy@med.unand.ac.id Telp : 081363489029, dr.desyambriani@gmail.com Telp : 08117390088 , Vitresia@gmail.com Telp : 08126647808
}

\section{PENDAHULUAN}

Abses subperiosteal orbita adalah komplikasi dari sinusitis paranasal, yang memiliki resiko kebutaan atau kematian. ${ }^{1}$ Abses subperiosteal merupakan hasil akumulasi pus purulen antara periorbita dan lamina papiracea dan penyebabnya paling umum adalah inflamasi sinus etmoid. ${ }^{2-5}$ 
Abses subperiosteal orbita jarang terjadi pada orang dewasa. ${ }^{5}$ Insiden abses subperiosteal kurang dari $1 \%$ namun dari $50 \%$ kasus ini menyebabkan gangguan penglihatan akibat tekanan tekanan pada orbita. $^{1,3}$ Klasifikasi komplikasi orbita menurut Chandler terbagi menjadi 5 yaitu: selulitis preseptal, selulitis orbita, abses subperiosteal, abses orbita, thrombosis sinus kavernosus. ${ }^{6}$

\section{Anatomi Sinus Paranasal}

Sinus paranasal adalah ruang berisi udara yang terletak didalam tulang tengkorak dan wajah. Hidung dan sinus paranasal memiliki beberapa fungsi diantaranya sebagai fungsi pernapasan untuk respirasi, filtrasi dari udara inspirasi, humidifikasi dari udara inspirasi, mengantur suhu, fungsi penciuman dan fungsi fonasi untuk memberikan kemampuan bicara. $^{7}$

Sinus paranasal terbagi menjadi dua kelompok besar yang terletak pada bagian anterior dan posterior. Sinus bagian anterior terdiri dari sinus maksila, sinus etmoid anterior dan sinus frontal sedangkan bagian posterior terdiri dari sinus sfenoid dan sinus etmoid posterior. Sinus kelompok anterior mengalir ke meatus media, sinus etmoid posterior mengalir ke meatus superior dan sinus sfenoid mengalir ke resesus sfenoetmoidalis. ${ }^{7,8}$

Kompleks ostiomeatal atau KOM adalah jalur pertemuan drainase kelompok sinus anterior yang terdiri dari meatus media, prosesus unsinatus, hiatus semilunaris, infundibulum ethmoid, bula ethmoid, ostium sinus maksila dan resesus frontal. Jika KOM mengalami obstruksi karena mukosa yang inflamasi atau massa maka akan terjadi stasis silia dan terjadi infeksi sinus. ${ }^{7}$

\section{Rinosinusitis Kronik}

Rinosinusitis kronis (RSK) adalah penyakit inflamasi mukosa hidung dan sinus paranasal yang berlangsung lebih dari 12 minggu. ${ }^{9,10}$ Prevalensi RSK di Amerika Serikat sekitar $13-16 \%$ pertahun. ${ }^{11}$ Data kunjungan poliklinik THT-KL RSUP Dr M Djamil Padang tahun 2012 mendapatkan 63 kasus rhinosinusitis kronis yang berobat. Paling banyak terjadi pada kelompok usia 46-55 tahun $(22,22 \%)$ dan lebih banyak terjadi pada perempuan $(60,32 \%){ }^{12}$

\section{Etiologi}

Etiologi dari RSK diduga bersifat multifaktorial yakni ada peran dari faktor pejamu dan lingkungan. Faktor lokal pejamu berupa inflamasi lokal yang persisten, gangguan anatomi sinus, tumor yang mengakibatkan obstruksi pada sinus sementara faktor sistemik pejamu berupa predisposisi genetik, keadaan imunosupresi dan penyakit genetik seperti fibrosis kistik dan dyskinesia silia. Faktor lingkungan berupa bakteri, virus, fungi, polusi, merokok dan alergi. Faktor lingkungan berupa septum deviasi, konka bulosa, konka media paradox, sel haller, sel khun dan anomaly kraniofasial. ${ }^{13,14}$

\section{Patofisiologi}

Kegagalan aliran mukus dan menurunnya ventilasi sinus merupakan faktor utama berkembangnya rinosinusitis. Inflamasi mukosa hidung akan memicu terjadinya pembengkakan dan eksudasi yang akan mengakibatkan terjadinya obstruksi ostium sinus. Obstruksi ostium sinus akan mengakibatkan terjadinya gangguan ventilasi, drainase dan resorpsi oksigen dirongga sinus yang berujung pada terjadinya hipoksia sehingga akan meningkatkan permeabilitas kapiler dan sekresi kelenjar. Efek berulang dari transudat dan peningkatan eksudasi serosa dikombinasikan dengan penurunan fungsi silia akan mengakibatkan retensi sekresi disinus. ${ }^{13}$

Stasis sekresi didalam sinus dapat dipicu oleh obstruksi mekanik dari edema mukosa yang diakibatkan berbagai macam etiologinya. Stagnansi mukus dalam sinus menjadi media pertumbuhan patogen yang baik. Pada saat respons inflamasi terus berlanjut diikuti dengan infeksi yang persisten, respon bakteri mengambil alih lingkungan sinus sehingga berubah ke keadaan yang lebih anaerob. ${ }^{16}$

Perubahan lingkungan bakteri ini dapat menyebabkan peningkatan organisme yang resisten dan menurunkan efektivitas antibiotik akibat ketidakmampuan antibiotik mencapai sinus. Infeksi akan menyebabkan 30\% mukosa kolumnar bersilia mengalami perubahan metaplastik menjadi mucus secreting goblet cells, sehingga efusi sinus makin meningkat. Inflamasi yang berlangsung lama (kronik) sering mengakibatkan penebalan mukosa disertai kerusakan silia sehingga ostium sinus semakin buntu. 
Mukosa yang tidak dapat kembali normal setelah inflamasi akut dapat menyebabkan gejala persisten dan mengarah pada rinosinusitis kronik. ${ }^{16}$

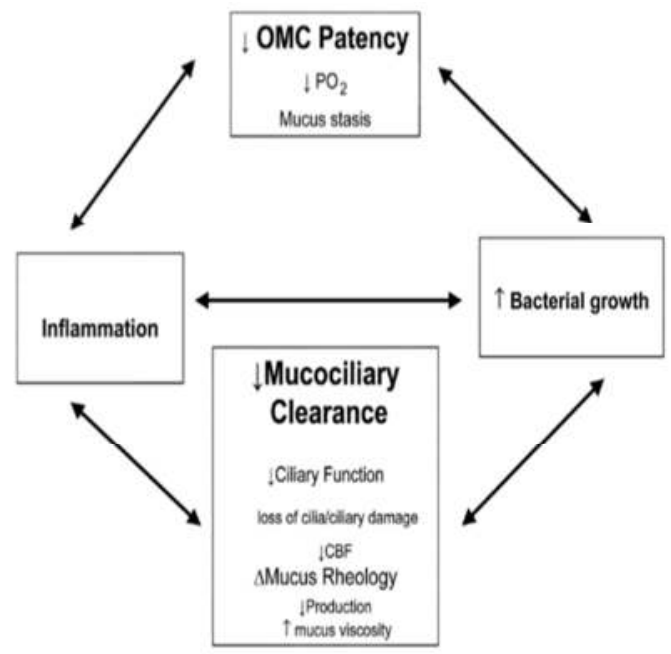

Gambar 1. Siklus patologis $\mathrm{RSK}^{13}$

Penyebaran infeksi rinosinusitis ke orbita dapat melalui penyebaran langsung melalui defek kelainan bawaan, foramen atau garis sutura yang terbuka, erosi tulang terutama pada lamina papirasea dan tromboflebitis retrograd langsung melalui pembuluh darah vena yang tidak berkatup yang menghubungkan orbita dengan wajah, kavum nasi, dan sinus paranasal. $^{17}$

\section{Gejala Kilinis}

Diagnosis rinosinusitik kronik ditegakkan melalui anamnesis, pemeriksaan fisik maupun pemeriksaan penunjang. Gejala lokal rinosinusitik kronik berupa obstruksi nasi, nasal discharge, nyeri kepala, nyeri wajah serta gangguan penghidu. Selain gejala lokal terdapat juga gejala-gejala lain yang disebabkan karena iritasi pada faring, laring dan juga trakea berupa batuk, disfoni, sesak dan nyeri tenggorok. Gejala sistemik berupa malaise dan demam. ${ }^{10}$

Sakit kepala merupakan salah satu tanda yang paling umum dan paling penting pada sinusitis. Nyeri kepala yang timbul merupakan akibat adanya kongesti dan edema di ostium sinus dan sekitarnya. Sakit kepala yang bersumber dari sinus akan meningkat jika membungkukkan badan dan jika badan tiba-tiba digerakkan. ${ }^{18}$

Menurut European Position Paper on Rhinosinusitis and Nasal Polyps (EPOS) 2012, gejala rinosinusitis kronis pada orang dewasa ditandai dengan dua gejala atau lebih, salah satunya harus berupa hidung tersumbat atau obstruksi atau kongesti atau ingus kental dari anterior/posterior dengan gejala lain nyeri wajah/rasa tertekan diwajah, gangguan penghidu dan salah satu dari temuan nasoendoskopi yaitu polip dan atau sekret mukopurulen dari meatus media dan atau edema atau obstruksi mukosa dimeatus media dan atau perubahan gambaran Computed Tomography Scan (CT Scan) berupa perubahan mukosa dikompleks osteomeatal dan atau sinus. ${ }^{10,15,19}$

\section{Komplikasi Orbita}

Regio orbita berbatasan dengan sinus frontal, etmoid dan maksila, sehingga infeksi sinus dapat berpotensi menyebar ke orbita. Berhubungan juga dengan ketebalan dinding sinus yang melapisi orbita. Semakin tipis dindingnya semakin mudah penyebaran infeksi. Sinus etmoid memiliki dinding yang paling tipis yaitu lamina papiracea yang melapisi dinding lateral sinus dan dinding medial orbita. Jika terbentuk abses antara dinding dan periosteum disebut abses subperiosteal. ${ }^{16,20}$

Klasifikasi komplikasi orbita menurut Chandler yaitu :22,23

1. Selulitis periorbita: peradangan pada kelopak mata yang ditandai dengan edema pada kelopak mata.

2. Selulitis orbita: peradangan dan edema sudah meluas ke orbita, ditandai dengan adanya proptosis, kemosis dan gangguan pergerakan bola mata. Biasanya bisa meluas menjadi abses orbita dan kebutaan.

3. Abses periorbita (abses subperiosteal): pembentukan dan pengumpulan pus antara periorbita dan dinding tulang orbita, yang ditandai dengan proptosis dengan perubahan letak bola mata, gangguan pergerakan bola mata dan penurunan visus.

4. Abses orbita: terdapat pembentukan dan pengumpulan pus di orbita ditandai dengan optalmoplegi, proptosis dan kehilangan penglihatan.

5. Trombosis sinus kavernosus: sudah terjadi perluasan infeksi ke sinus kavernosus yang ditandai dengan proptosis, optalmoplegi, 
kehilangan penglihatan disertai perluasan tanda infeksi ke mata yang sehat dan tanda-tanda meningitis.

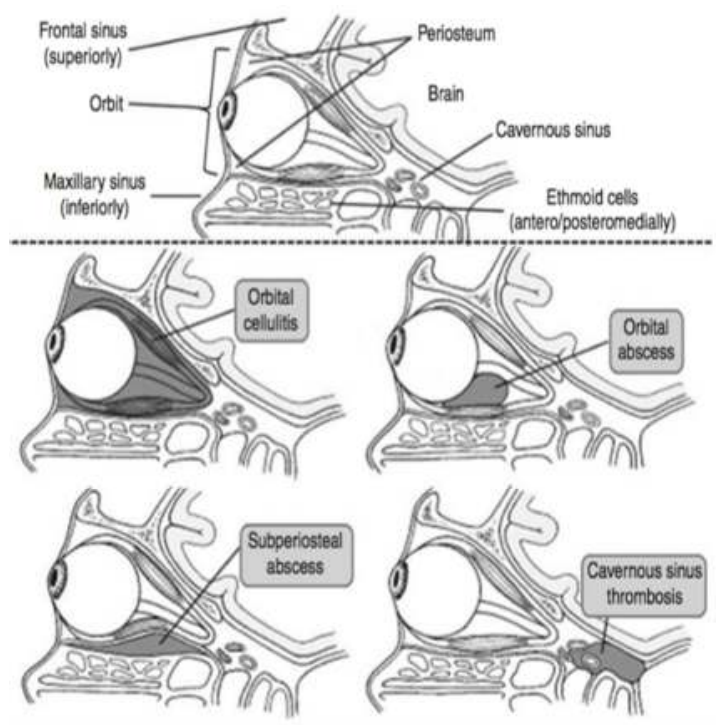

Gambar 2. Komplikasi Orbita ${ }^{21}$

\section{Penatalaksanaan Komplikasi Orbita}

Medikamentosa adalah terapi pilihan pada kebanyakan pasien. Agar terapi berhasil, terlebih dahulu pasien dikelompokkan menjadi kelompok resiko rendah dan resiko tinggi berdasarkan komplikasinya. Kelompok resiko rendah yaitu: Umur dibawah 9 tahun, tidak ada gangguan penglihatan, abses ukuran sedang pada sisi medial orbita, tidak ada komplikasi intracranial, dapat mengikuti rangkaian tes oftalmoplegia dan tidak ada gangguan status imun. Pada 90\% pasien dengan resiko tinggi berhasil diterapi dengan antibiotik saja. ${ }^{17}$

Penatalaksanaan rinosinusitis kronis dengan komplikasi orbita dapat berupa pemberian medikamentosa baik antibiotik intravena dengan spektrum luas dan atau kombinasi, dekongestan, kortikosteroid sistemik maupun disertai dengan tindakan operatif. ${ }^{24,25}$

Pada abses subperiosteal, selain terapi medikamentosa dilakukan juga drainase abses dan eradikasi sumber infeksi pada sinus yang terlibat. Pada abses orbita diberikan terapi medikamentosa dan operatif berupa drainase abses dan orbitotomi untuk dekompresi saraf optik. ${ }^{25}$ Umumnya tindakan operatif dilakukan bila terdapat kegagalan terapi medikamentosa yang optimal dalam 48 jam rawatan atau sudah terdapat komplikasi orbita yaitu penurunan visus dan atau komplikasi intrakranial. ${ }^{24-26}$

\section{KASUS}

Seorang pasien laki-laki umur 40 tahun dikonsulkan ke bagian THT pada tanggal 2 Juni 2018 dari bagian Mata dengan diagnosa selulitis preseptal okuli sinistra dan sinusitis maksila sinistra. Dari anamnesis didapatkan keluhan utama bengkak dan nyeri pada kelopak mata kiri semakin memberat sejak 3 hari sebelum masuk rumah sakit. Awalnya pasien sudah mengeluhkan keluhan hidung kiri tersumbat, rasa berat di pipi kiri, rasa ingus mengalir ketenggorok dan sudah berobat kedokter umum namun tidak sembuh sejak satu tahun yang lalu disertai bengkak pada kelopak mata yang hilang timbul. Terdapat penciuman berkurang dan tidak terdapat gangguan penglihatan. Keluhan hidung berbau tidak ada, demam tidak ada. Riwayat sakit gigi kiri atas ada namun sudah dicabut sejak 10 tahun yang lalu. Tidak didapatkan keluhan pada telinga, tenggorok. Riwayat alergi, trauma, hipertensi dan kencing manis disangkal.

Pada pemeriksaan fisik didapatkan keadaan umum pasien baik, komposmentis, suhu afebris. Pemeriksaan otoskopi kedua telinga didapatkan liang telinga lapang, membran timpani utuh, refleks cahaya ada. Pemeriksaan rinoskopi anterior didapatkan kavum nasi kiri sempit, konka inferior udem, konka media udem, septum deviasi tidak ada, sekret mukopurulen. Kavum nasi kanan lapang, konka inferior dan konka media eutrofi, septum ditengah, tidak ditemukan sekret. Pemeriksaan rinoskopi posterior terlihat post nasal drip mukopurelen dan tenggorok dalam batas normal.

Pada pemeriksaan mata kiri terlihat bengkak dipalpebra superior, hiperemis, nyeri tekan ada, nyeri menggerakan bola mata tidak ada, keterbatasan gerakan bola mata tidak ada, visus tidak terganggu. Pemeriksaan mata kanan dalam batas normal.

Pemeriksaan fisik bagian mata didapatkan daerah fluktuatif dipalpebra superior $1 / 3$ lateral dengan kesan abses palpebra OS: 
Tabel 1. Status oftalmologi (1-06-2018)

\begin{tabular}{|c|c|c|}
\hline $\begin{array}{l}\text { Status } \\
\text { Optikus }\end{array}$ & OD & OS \\
\hline Visus & $20 / 20$ & $20 / 20$ \\
\hline Palpebra & Udem (-) & $\begin{array}{c}\text { Udem }(+) \text { superior } \\
1 / 3 \text { lateral kenyal } \\
\text { Hiperemis }(+) \\
\text { Nyeri tekan }(+)\end{array}$ \\
\hline Konjungtiva & Hiperemis (-) & $\begin{array}{l}\text { Kemosis }(+) \\
\text { Hiperemis }(+)\end{array}$ \\
\hline Kornea & Bening & Bening \\
\hline COA & Cukup dalam & Cukup dalam \\
\hline Pupil & $\begin{array}{l}\text { Bulat } 3 \mathrm{~mm} \\
\qquad \mathrm{Rf}+/+\end{array}$ & $\begin{array}{l}\text { Bulat } 3 \mathrm{~mm} \\
\qquad \mathrm{Rf}+/+\end{array}$ \\
\hline Lensa & Bening & Bening \\
\hline TIO & Normal & Normal \\
\hline Funduskopi & Baik & Baik \\
\hline Gerakan & Bebas & Bebas \\
\hline
\end{tabular}

Hasil pemeriksaan nasoendoskopi didapatkan kavum nasi kiri sempit, konka inferior eutrofi, konka media udem, hiperemis, meatus media tertutup, terlihat sekret mukopurulen dimeatus media, septum deviasi tidak ada, tampak sekret mukopurulen mengalir hingga nasofaring.

Pemeriksaan penunjang Computed Tomografi ICT Scan (Gambar 3) menunjukkan tampaknya soft tissue swelling di regio palpebra sinistra. Tampak adanya perselubungan isodens relatif homogen dianterior bulbus okuli sinistra, anterior septum orbita. Bulbus okuli dekstra dan sinistra baik, bentuk dan ukuran normal, korpus vitreum homogen, lensa normal. Nervus optikus dekstra dan sinistra dalam batas normal. Tampak perselubungan pada sinus maksilaris dan etmoidalis sinistra serta frontalis sinistra. Kesan selulitis orbita sinistra, sinusitis maksilaris sinistra, etmoidalis sinistra dan frontalis sinistra.

Pemeriksaan laboratorium darah menunjukkan lekosit (13.390/mm3), Hb (13,1 g/dl), Trombosit (326000/mm3), Hematokrit (40\%), GDS (203 mg/dl). Kesan leukositosis dengan hiperglikemi.

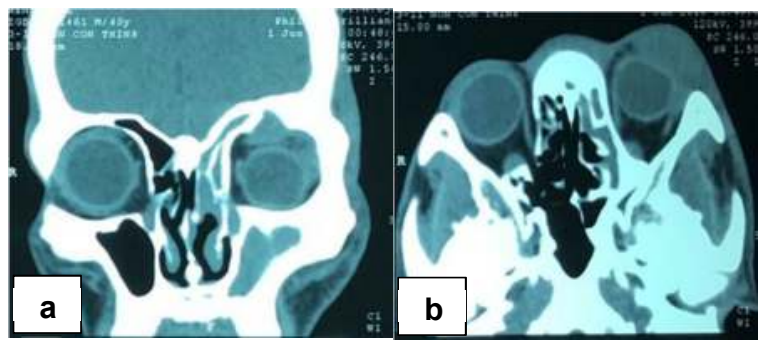

Gambar 3. CT Scan Mata Rekon potongan koronal (a) dan axial (b)
Pasien saat ini didiagnosis multirinosinusitis kronis (maksila sinistra, etmoid sinistra, frontal sinistra) dengan suspek selulitis preseptal okuli sinistra. Pasien dirawat bersama dengan bagian Mata dibangsal Mata, sesuai dengan protap di bagian THT-KL Unand RSUP Dr. M. Djamil Padang pasien diberikan terapi vancomisin $2 \times 1$ gram, metronidazole drip $3 \times 500 \mathrm{mg}$, metilprednisolon injeksi $3 \times 125 \mathrm{mg}, \quad$ N.Asetilsistein tablet $3 \times 200 \mathrm{mg}$, pseudoefedrin $30 \mathrm{mg}+$ terfenadin 40 $\mathrm{mg} 3 \times 1$, parasetamol tablet $3 \times 500 \mathrm{mg}$, cuci hidung Nacl 0,9\% 5x20 cc lubang hidung kiri dan kanan dan direncanakan dekompresi orbita dengan pendekatan BSEF bersama bagian Mata untuk eksisi palpebra superior okuli sinistra dalam narkose umum bila keluhan tidak ada perbaikan atau ada keluhan penurunan penglihatan.

Tabel 2. Status oftalmologi (4-06-2018)

\begin{tabular}{|c|c|c|}
\hline Status & OD & OS \\
\hline \multicolumn{3}{|l|}{ Optikus } \\
\hline Visus & $20 / 20$ & $20 / 40$ \\
\hline \multirow[t]{4}{*}{ Palpebra } & Udem (-) & Udem $(+)$ superior \\
\hline & & $1 / 3$ lateral kenyal \\
\hline & & Hiperemis (+) \\
\hline & & Nyeri tekan (+) \\
\hline \multirow[t]{2}{*}{ Konjungtiva } & Hiperemis (-) & Kemosis (+) \\
\hline & & Hiperemis (+) \\
\hline Kornea & Bening & Bening \\
\hline $\mathrm{COA}$ & Cukup dalam & Cukup dalam \\
\hline \multirow[t]{2}{*}{ Pupil } & Bulat $3 \mathrm{~mm}$ & Bulat $3 \mathrm{~mm}$ \\
\hline & $\mathrm{Rf}+/+$ & $\mathrm{Rf}+/+$ \\
\hline Lensa & Bening & Bening \\
\hline TIO & Normal & Normal \\
\hline Funduskopi & Baik & Baik \\
\hline Gerakan & Bebas & Bebas \\
\hline Posisi & & \\
\hline
\end{tabular}

Pada tanggal 4 Juni 2018, pasien mengeluhkan penurunan penglihatan pada mata sebelah kiri, mata kanan terasa nyeri, bengkak dimata kiri bertambah, ingus tertelan masih ada. Pemeriksaan ulang laboratorium didapatkan hasil lekosit 24.510/mm3, gula darah puasa $129 \mathrm{mg} / \mathrm{dl}$, GDS $230 \mathrm{mg} / \mathrm{dl}$. Pemeriksaan fisik bagian mata didapatkan kesan penurunan visus OS (Tabel 2).

Pasien dikonsulkan kebagian Penyakit Dalam untuk hiperglikemia dan persiapan operasi. Pasien didiagnosa multirinosinusitis kronis dengan komplikasi 
curiga abses periorbita okuli sinistra dan diabetes melitus tipe-2, diberikan terapi sliding scale insulin subkutan.

Pada tanggal 7 Juni 2018 dilakukan operasi dekompresi orbita dengan pendekatan bedah sinus endoskopi dan insisi evakuasi abses palpebra superior okuli sinistra. Pasien berbaring telentang di meja operasi dalam narkose umum. Dipasang oral pack, dilakukan tindakan aseptik dan antiseptik pada lapangan operasi dan ditutup kain steril. Dilakukan pemasangan tampon hidung epinefrin: lidokain (1:4) pada KNS dan ditunggu selama 10 menit. Evaluasi KNS dengan scope 00 , terlihat sekret mukopurulen di meatus media, konka inferior eutropi dan konka media edem. Dilakukan unsinektomi dan pelebaran ostium sinus maksila sinistra tampak sekret mukopurulen lalu disedot untuk dilakukan dikultur. Dilanjutkan etmoidektomi dan pelebaran ostium sinus frontalis. Bersamaan dengan penekanan pada mata kiri, keluar sekret dari sinus frontal lalu disedot dan dibersihkan. Perdarahan diatasi, dipasang tampon handscoen 1-0 longgar yang telah diolesi betadin dan salf kloramfenikol, oral pack dikeluarkan. Operasi dilanjutkan bagian Mata, dilakukan aspirasi pada palpebra superior OS, terdapat pus $5 \mathrm{cc}$. Dilakukan kuret dan pencucian daerah insisi, dipasang drain, dilakukan penjahitan pada insisi kemudian ditutup dengan perban, operasi selesai (Gambar 4).

Diagnosis pasca operasi pasca bedah sinus endoskopi fungsional adalah multirinosinusitis kronis dengan komplikasi abses subperiosteal okuli sinistra + post insisi dan eksplorasi abses palpebra superior OS. Terapi setelah operasi diberikan vancomisin 2x1 gram, metronidazole drip $3 \times 500 \mathrm{mg}$, drip tramadol 3x1 amp, N.Asetilsistein tablet $3 \times 200 \mathrm{mg}$, pseudoefedrin $30 \mathrm{mg}$, dan terfenadin $40 \mathrm{mg} 3 \times 1$.

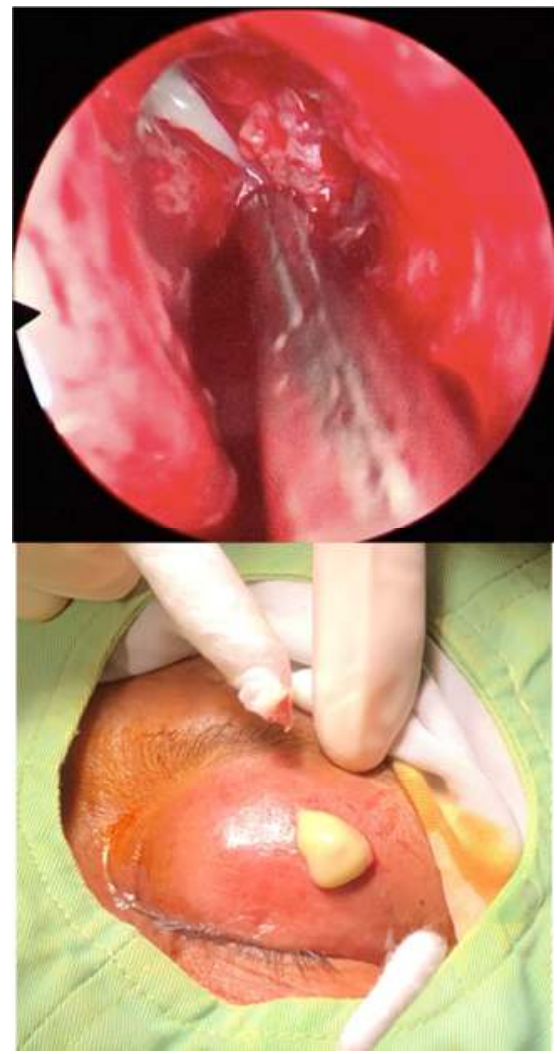

Gambar 4. Intra operatif

Rawatan hari ke-1 pasca operasi, darah merembes tidak ada, nyeri dan bengkak berkurang, gangguan penglihatan tidak ada, demam tidak ada.

Tabel 3. Pemeriksaan fisik bagian Mata

\begin{tabular}{ccc}
\hline $\begin{array}{c}\text { Status } \\
\text { Optikus }\end{array}$ & OD & OS \\
\hline Visus & $20 / 20$ & $20 / 20$ \\
Palpebra & Udem (-) & Udem (+) \\
& & Hiperemis (+) \\
& & Nyeri tekan (-) \\
Konjungtiva & Hiperemis (-) & Hiperemis (-) \\
Kornea & Bening & Bening \\
COA & Cukup dalam & Cukup dalam \\
Pupil & Bulat 3 mm & Bulat 3 mm \\
& Rf $+/+$ & Rf $+/+$ \\
Lensa & Bening & Bening \\
TIO & Normal & Normal \\
\hline
\end{tabular}


Tanggal 9 Juni 2018 (rawatan hari ke-3 pasca operasi) bengkak pada mata berkurang, gangguan penglihatan tidak ada, demam tidak ada, nyeri pada luka tidak ada. Tampon hidung dibuka, kavum nasi sempit, terlihat konka inferior edema, konka media edema, darah mengalir tidak ada, terlihat sekret mukoid putih kekuning, krusta ada. Sedangkan kavum nasi dekstra dalam batas normal. Hasil pemeriksaan GDS didapatkan $146 \mathrm{mg} / \mathrm{dl}$. Pasien kemudian dibolehkan pulang dan diberi terapi ciprofloksasin tablet $2 \times 500 \mathrm{mg}$, metronidazol tablet $3 \times 500 \mathrm{mg}$, $\mathrm{N}$.asetil sistein $3 \times 200 \mathrm{mg}$, cetirizine $1 \times 1$. Dari bagian mata gangguan penglihatan tidak ada dan diberi tambahan terapi kloramfenikol salf mata.

Pada hasil kultur dari sekret yang diambil saat dilakukan operasi dekompresi menunjukkan tidak ditemukannya pertumbuhan kuman. Kontrol pertama tanggal 22 Juni 2018 (2 minggu pasca rawatan), tidak ditemukan ingus yang keluar dari hidung atau tertelan di tenggorok, hidung masih tersumbat, nyeri hidung tidak ada, demam tidak ada. Pemeriksaan kavum nasi kiri lapang, terlihat konka inferior uutrofi, konka media eutropi, meatus media terbuka, terdapat sekret mukoid putih dan krusta. Kavum nasi dibersihkan dan terapi sebelumnya dilanjutkan, ditambahkan cuci hidung dengan $\mathrm{NaCl}$ 0,9\%. Kontrol pada bagian mata 25 Juni 2018, keluhan tidak ada.

Tabel 4. Pemeriksaan fisik bagian Mata

\begin{tabular}{ccc}
\hline $\begin{array}{c}\text { Status } \\
\text { Optikus }\end{array}$ & OD & OS \\
\hline Visus & $20 / 20$ & $20 / 20$ \\
Palpebra & Udem (-) & Udem (-) \\
Konjungtiva & Hiperemis (-) & Hiperemis (-) \\
Kornea & Bening & Bening \\
COA & Cukup dalam & Cukup dalam \\
Pupil & Bulat 3 mm & Bulat 3 mm \\
Lensa & Bening & Bening \\
TIO & Normal & Normal \\
Funduskopi & Baik & Baik \\
Gerakan & Bebas & Bebas
\end{tabular}

Kontrol tanggal 29 Juni 2018, tidak ditemukan ingus yang keluar dari hidung atau tertelan di tenggorok, hidung tidak tersumbat, hidung dan wajah tidak nyeri, demam tidak ada. Pemeriksaan kavum nasi kiri terlihat konka inferior dan konka media eutropi, terdapat sekret mukoid dan krusta minimal. Kavum nasi dibersihkan dan terapi dengan cuci hidung Nacl 0,9\% 4x20 cc, nasocort sprey 1×2 spray.

Kontrol tanggal 13 Juli 2018, ditemukan ingus yang keluar dari hidung atau tertelan di tenggorok, hidung tidak tersumbat, hidung dan wajah tidak nyeri, demam tidak ada. Kavum nasi kiri lapang, terlihat konka inferior dan konka media eutropi, tidak terdapat sekret. Terapi tidak ada. Terapi cuci hidung Nacl 0,9\% dilanjutkan.

\section{PEMBAHASAN}

Dilaporkan satu kasus seorang laki-laki umur 40 tahun dengan diagnosa multirinosinusitis kronis dengan komplikasi abses subperiosteal okuli sinistra yang ditegakkan berdasarkan anamnesis, pemeriksaan fisik THT dan mata, serta pemeriksaan penunjang CT Scan. Beberapa literatur menyebutkan bahwa selain penyebaran infeksi sinus paranasal, selulitis preseptal, selulitis orbita atau abses periorbita (subperiosteal) bisa disebabkan karena trauma pada orbita, infeksi di sistem lakrimal, infeksi pada kulit di daerah mata atau operasi daerah orbita. ${ }^{16,22}$ Penyebab tersebut dapat disingkirkan pada kasus ini dengan anamnesis yang terarah.

Pada kasus ini saat awal rawatan didiagnosis kerja dengan selulitis preseptal namun karena tidak ada perbaikan setelah dirawat selama 2 hari dan sudah ada penurunan visus pada mata kiri maka sesuai dengan protap di bagian THT-KL Unand RSUP Dr. M. Djamil Padang pasien dilakukan operasi dekompresi orbita dengan pendekatan BSEF dan insisi evakuasi abses palpebra superior okuli sinistra. Saat intraoperatif terlihat pus mengalir dari dinding medial orbita sinistra (lamina papirasea) dan ostium sinus frontalis bersamaan dengan penekanan pada mata kiri sehingga pasien didiagnosis abses periorbita. Adanya proses inflamasi yang berlanjut karena tidak adekuatnya pemberian antibiotik, virulensi kuman yang tinggi atau terdapatnya infeksi campuran lebih dari satu kuman sehingga antibiotik yang diberikan tidak dapat mengeradikasi semua kuman yang menyebabkan proses selulitis obita berlanjut menjadi abses subperiosteal. ${ }^{17,25}$

Abses subperiosteal merupakan proses infeksi yang ditandai dengan kumpulan abses antara lamina 
papirasea dengan periorbita. Kumpulan pus antara lamina papirasea dengan periorbita menyebabkan proptosis. $^{25}$

Pada anamnesis didapatkan keluhan pilek, hidung tersumbat, rasa berat di pipi kiri, rasa ingus mengalir ketenggorok dan penciuman berkurang yang tidak sembuh sejak satu tahun yang lalu dan pada pemeriksaan nasoendoskopi didapatkan sekret mukopurulen dimeatus media ini. Dari keluhan yang dinyatakan pasien dan hasil pemeriksaan nasoendoskopi pasien telah memenuhi 2 kriteria dalam menegakan diagnosis rhinosinusitis kronik. ${ }^{9,10}$ Kemudian ditambah lagi dengan keluhan bengkak dan nyeri pada kelopak mata kiri, nyeri dan sukar menggerakan bola mata tidak ada ini sesuai dengan klasifikasi Chandler komplikasi orbita yaitu selulitis preseptal. $^{17,25}$

Pemeriksaan CT Scan serta MRI dapat membantu mengidentifikasi stadium komplikasi orbita sehingga pilihan terapi yang efektif bisa ditentukan. ${ }^{26}$ Hasil CT Scan paranasal pada pasien ini tampak perselubungan pada sinus maksilaris dan etmoidalis sinistra serta frontalis sinistra, perselubungan isodens relative homogen dianterior bulbus okuli sinistra dan anterior septum orbita. Gambaran ini sesuai dengan literatur yang menunjukkan adanya tanda-tanda peradangan sinus paranasal disertai dengan proses inflamasi yang mengarah ke selulitis di daerah orbita.

Insiden komplikasi orbita yang disebabkan oleh rinosinusitis ini semakin berkurang setelah ditemukannya antibiotik, terutama kehilangan penglihatan hingga kematian karena penyebaran ke Intrakranial. ${ }^{27}$ Sesuai dengan panduan praktek klinik (PPK) bagian THT-KL Unand RSUP Dr. M. Djamil Padang pemberian antibiotik spektrum luas sinusitis kronis dengan komplikasi ke orbita yaitu meropenem atau vankomisin. Pada pasien ini diberikan terapi antibiotik intravena vankomisin kombinasi dengan metronidazole. Pemberian antibiotik secara empiris harus mencakup gram positif, gram negatif dan bakteri anaerob untuk mengobati organisme paling umum yang berhubungan dengan penyakit ini.

Al-Madani menyebutkan bahwa dari 616 pasien sinusitis, komplikasi orbita ditemukan 36 pasien $(5,8 \%), 26$ pasien adalah anak-anak (72,2 \%) dan sisanya 10 pasien $(27,8 \%)$ adalah dewasa. Tersering ditemui adalah selulitis preseptal didapat 72,2 \%, diikuti selulitis orbital 22,2 \% dan abses 5,6 \%.28 Disebutkan juga bahwa kejadian paling sering pada laki-laki dengan rasio $2: 1$ dan paling sering terkena anak umur $<5$ tahun. $^{28}$ Hampir sama dengan Nwaogru et al, yaitu dari 90 pasien, laki-laki lebih sering terkena (2:1), umur antara 3,5 - 66 tahun, ditemukan 47 pasien (52\%) di diagnosis sinusitis dengan komplikasi selulitis orbita. ${ }^{29} \mathrm{Hal}$ ini juga dipengaruhi oleh beberapa faktor seperti anatomi antara sinus paranasal dan orbita, kekebalan tubuh yang menurun terutama pasien dengan imunodefisiensi, serta faktor lingkungan seperti kebersihan, musim, ataupun alergen. ${ }^{15}$

Penatalaksanaan komplikasi orbita tergantung pada stadium dari klasifikasi Chandler. Kebanyakan kasus selulitis preseptal dan selulitis orbita penanganannya dengan pemberian antibiotika intravena. ${ }^{9}$ Choi dan Grundfast memperkirakan bahwa sekitar $60 \%$ dari komplikasi orbital membutuhkan intervensi bedah. ${ }^{24}$

Pada kasus ini diindikasikan untuk tindakan operatif dekompresi orbita dengan bedah sinus endoskopi fungsional karena tidak ada perbaikan setelah 48 jam setelah pemberian antibiotik intravena. Hal ini sesuai dengan literatur yang menyebutkan bahwa terapi pembedahan pada rinosinusitis dengan komplikasi orbita diindikasikan bila: ${ }^{17,21}$

1. Terlihat gambaran abses yang dibuktikan dengan CT Scan

2. Tidak terdapat perbaikan setelah 48 jam pemberian antbiotik yang adekuat.

3. Komplikasi orbita yang berat seperti kebutaan atau reflek pupil yang meningkat.

4. Penurunan fungsi penglihatan.

5. Peningkatan tanda proptosis dan oftalmoplegi.

Teknik pembedahan pada kasus ini dilakukan operasi dekompresi orbita dengan pendekatan BESF dan insisi evakuasi abses palpebra superior okuli sinistra. BESF yang dilakukan pada pasien ini meliputi tindakan unsinektomi, etmoidektomi dan dilakukan tindakan pembukaan dan pembersihan resesus frontalis. Saat evaluasi terlihat sekret mukopurulen yang mengalir dari sinus frontal sehingga sekret hanya dihisap melalui celah yang sudah ada bersamaan dengan penekanan pada bola mata. 
Pendekatan klinis terhadap diagnosis dan penatalaksanaan sinusitis telah mengalami perubahan selama beberapa tahun terakhir seiring dengan perkembangan di bidang mikrobiologi dan radiologi serta adanya teknik terbaru mengenai teknik bedah minimal invasif seperti BSEF. Bhargava et al juga menyebutkan bahwa dari tiga pasien sinusitis dengan komplikasi abses periorbita yang dilakukan bedah sinus endoskopi, semuanya sembuh tanpa komplikasi dan merekomendasikan BSEF sebagai teknik yang minimal invasif dan lebih aman dibandingkan pendekatan eksterna untuk drainase abses periorbita. Keberhasilan dengan pendekatan endoskopi transnasal tergantung pada keahlian dokter THT, jumlah perdarahan lokal dan sinus paranasal yang terlibat. $^{1}$

Prognosis pasien rinosinusitis dengan komplikasi orbita umumnya baik setelah ditemukannya antibiotik, pemeriksaan penunjang $\mathrm{CT}$ Scan hingga MRI, dan teknik pembedahan endoskopi yang minimal invasif. ${ }^{21}$ Komplikasi yang mungkin terjadi dapat berupa kehilangan penglihatan, gejala sisa neurologis hingga kematian. ${ }^{17,21}$ Neto et al menyebutkan dalam laporannya bahwa dari semua pasien sinusitis dengan komplikasi orbita yang diobati baik konservatif saja ataupun kombinasi dengan pembedahan, semuanya sembuh tanpa ada gejala sisa. ${ }^{30}$

Pasien tetap dianjurkan kontrol secara berkala untuk menilai keberhasilan operasi dan ada tidaknya gejala sisa ataupun kekambuhan. Pemberian obat antibiotik oral dan dekongestan tetap diberikan hingga infeksi sinus paranasal diyakini tidak ada lagi.

\section{SIMPULAN}

Penanganan masalah dengan pemberian antibiotik yang adekuat serta dengan teknik pembedahan Bedah sinus endoskopi fungsional serta dengan kontrol yang teratur dapat memberikan kesembuhan pada pasien.

\section{UCAPAN TERIMA KASIH}

Terimakasih kepada semua pihak yang senantiasa memberikan bantuan dan dukungan dalam pelaksanaan laporan kasus ini.

\section{DAFTAR PUSTAKA}

1. Bhargava D, Sankhla D, Ganesan A, Chand P. Endoscopic sinus surgery for orbital subperiosteal abscess secondary to sinusitis. Rhinology. 2001;39(3):151-5.

2. Harris GJ. Subperiosteal abscess of the orbit: age as a factor in the bacteriology and response to treatment. Ophthalmology. 1994;101(3):58595.

3. Gavriel H, Jabarin B, Israel O, Eviatar E. Conservative Management for subperiosteal orbital abscess in adults: A 20-Year experience. Ann Otol Rhinol Laryngol. 2018;127(3):162-6.

4. Neto $A D$ de A, Sampaio TR de C, Cavalcante DKF, Filho LLTN, Nogueira PTB de C, Filho JRL. Surgical approach of orbital subperiosteal abscess associated with the orbital fracture. Rev Bras Oftalmol. 2015;74(5):315-8.

5. Hong S, Im D. Surgery surgical management of orbital subperiosteal abscess caused by chronic rhinosinusitis in an adult patient. Clinics in Surgery. 2017;2(1307):2-3.

6. Cruz AAV, Demarco RC, Valera FCP, Dos Santos AC, Anselmo-Lima WT, Marquezini RMDS. Orbital complications of acute rhinosinusitis: A new classification. Braz J Otorhinolaryngol. 2007;73(5):684-8.

7. Hwang PE, Abdalkhani A. Embryology, anatomy and physiology of the nose and paranasal sinuses. Dalam: Snow JB, Wackym PA, editor (penyunting). Ballenger's otorhinolaryngology: head and neck surgery. Centenial Edition. London: BC Decker Inc; 2009.hlm.455-64.

8. Sarah WK, Richard OR, John DM. Sinonasal development and anatomy. Dalam: Kennedy DW, Hwang $\mathrm{PH}$, editor (penyunting). Rhinology diseases of the nose, sinuses and skull base. Edisi ke-1. New York: Thieme; 2012. hlm.1-20.

9. Benninger GJ. Rhinosinusitis: Clinical presentation and diagnosis. Dalam: Itzhak B, editor (penyunting). Sinusitis from Microbiology to management. Michigan, U.S.A: CRC Press; 2006.hlm.39-53. 
10. Fokkens JF, Chair, Lund VJ, Chair C, Mullol J, Chair C, et al. European position paper on rhinosinusitis and nasal polyps 2012. EPOS. 2012:1-12.

11. Petel MZ, Hwang HP. Non Polypoid rhinosinusitis: Pathogenesis, diagnosis, Staging and treatment. Dalam: Johnson JT, Rosen CA, editor (penyunting). Bailey's head and neck surgery otolaryngology. Edisi ke-5. Philadelphia: Lippincot Williams \& Wilkins; 2014.hlm.535-49.

12. Trihastuti H, Budiman BJ E. Artikel penelitian profil pasien rinosinusitis kronik di poliklinik THTKL RSUP. J Kesehat Andalas. 2012;4(3):877-82.

13. Jackman $\mathrm{H}$ Alexis, $\mathrm{W}$ KD. Pathophysiology of sinusitis. Dalam: Itzhak B, editor (penyunting). Sinusitis from microbiology to management. Michigan, USA: CRC Press; 2006.hlm.109-34.

14. Hamilos DL. Chronic rhinosinusitis: Epidemiology and medical management. J Allergy Clin Immunol. 2011;128(4):693-707.

15. Matthew RW. Chronic rhinosinusitis with nasal polyposis. Dalam: Johnson JT, Rosen CA, editor (penyunting). Bailey's head and neck surgery otolaryngology. Edisi ke-5. Philadelphia: Lippincot Williams \& Wilkins; 2014.hlm.525-34.

16. Brook I. Microbiology and antimicrobial treatment of orbital and intracranial complications of sinusitis in children and their management. Int $\mathrm{J}$ Pediatr Otorhinolaryngol. 2009;73(9):1183-6.

17. Gary S, Steve W. Complications of acute and chronic sinusitis and their management. Dalam: Itzhak B, editor (penyunting). Sinusitis from microbiology to management. Michigan, USA: CRC Press; 2006.hlm.269-90.

18. Rodney JS, A WB. Chronic rhinosinusitis and polyposis. Dalam: Ballenger's Otorhinolaryngology head and neck surgery. People's Medical Publishing House; 2009:573-82.

19. Victoria EA. The Diagnosis of Rhinosinusitis. Dalam: Gralapp C, Hwang PH, Kennedy DW, editor (penyunting). Rhinology: Diseases of the nose, sinuses and skull base. Thieme; 2012:11025.

20. Kong $\mathrm{MH}$, Jemaima $\mathrm{CH}$, Rona $\mathrm{AN}$, Balwant SG. Endoscopic drainage of superior subperiosteal orbital abscess. East J Med. 2014;19:194-7.
21. Kastner J, Simmen D, Netuka D, Sr JK, Gudziol V. Orbital and intracranial complications of acute and chronic rhinosinusitis. Springer. 2014:496515.

22. Andrea $\mathrm{H}$, Simone $\mathrm{F}$. Periorbital and orbital cellulitis. Pediatr Infect Dis J. 1987;6(4):404-10.

23. Goldstein BJ. Orbital complications of sinuses. Dalam: Goldenberg D, Goldstein BJ, editor (penyunting). Handbook of otolaryngology head and neck surgery. Edisi ke-2. New York: Thieme; 2010.hlm.219-21.

24. Choi SS, Grundfast KM. Complications in Sinus Disease. Dalam: Kennedy DW, Bolger WE, Zinreich SJ. Disease of the sinuses diagnosis and management. London: BC Decker Inc; 2001. hlm.169-77.

25. Giannoni CM. Complications of rhinosinusitis. Dalam: Johnson JT, Rosen CA, editor (penyunting). Bailey's Head and neck surgery otolaryngology. Edisi ke-5. Philadelphia: Lippincot Williams \& Wilkins; 2014.hlm.573-85.

26. Cruz AAV, Demarco RC, Valera FCP, Dos Santos AC, Anselmo-Lima WT, Marquezini RMDS. Orbital complications of acute rhinosinusitis: A new classification. Braz J Otorhinolaryngol. 2007;73(5):684-8.

27. Bourlidou E, Kyrgidis A, Venetis G, Panacleridou T, Mangoudi D. Orbital abscess and inflammation of odontogenic origin. J Pioneer Med Sci. 2012; 2(3):92-7.

28. Al-Madani MV, Khatatbeh AE, Rawashdeh RZ, Al-Khtoum NF, Shawagfeh NR. The prevalence of orbital complications among children and adults with acute rhinosinusitis. Braz J Otorhinolaryngol. 2013;79(6):716-9.

29. Nwaorgu OGB, Awobem FJ, Onakoya PA, Awobem AA. Orbital cellulitis complicating sinusitis: a 15-year review. Niger J Surg Res. 2004;6(1):14-6.

30. Mekhitarian Neto L, Pignatari S, Mitsuda S, Fava AS, Stamm A. Acute sinusitis in children: a retrospective study of orbital complications. Rev Bras Otorrinolaringol (English ed). 2007; 73 (1): 75-9. 